\title{
MANUFACTURE OF A COMBINATION UNIT APPROPRIATE FOR WATER HARVESTING AND SOIL CONSERVATION UNDER RAINFED AGRICULTURAL CONDITIONS
}

\author{
Morad, M. M. ${ }^{*} \quad$ M. M. A. Ali** $\quad$ A. A. Ali ${ }^{* * * *} \quad$ A. S. El-Kot ${ }^{* * * *}$
}

\begin{abstract}
Experiments were carried out to manufacture and evaluate the performance of a combination unit suitable for water harvesting, planting, and soil conservation under rain fed agricultural conditions. The machine performance was studied as a function of change in machine forward speed and plowing depth. Performance evaluation of the manufactured machine was carried out in terms of bulk density, and infiltration rate as a soil measurements; crop yield as a crop measurements; runoff and water use efficiency as a water measurements; field capacity and efficiency, required power, energy requirements and operational cost as a machine measurements. The experimental results reveal that runoff volume, energy and cost were minimum while crop yield was maximum under the following conditions:

- $\quad$ The use of the developed unit for effective water harvesting and soil conservation.

- Machine forward speed of between 3.5 to $4.5 \mathrm{~km} / \mathrm{h}$.

- Plowing depth of between 10 to $15 \mathrm{~cm}$.
\end{abstract}

\section{INTRODUCTION}

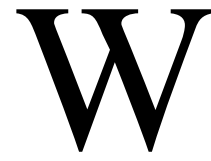
ater is essential to all life - human, animal and vegetation. It is therefore important that adequate supplies of water be developed to sustain such life. Development of water supplies should, however, be undertaken in such a way as to preserve the hydrological interest in the low balance and the biological functions of all ecosystems. This is crucial for marginal lands. Water harvesting (WH) is defined as the process of concentrating rainfalls runoff from a larger area for use in a smaller target area where the collected water is either directly

\footnotetext{
"Prof. of Agric. Eng., Fac. of Agric., Zagazig Univ., Egypt.

"** Assoc. Prof. of Agric. Eng., Fac. of Agric., Zagazig Univ., Egypt.

**** Assoc. Prof. of Soil Conservation, D.R.C Egypt.
} 
applied to the cropping area and stored in the soil profile for immediate use by the crop. The role of water harvesting systems in semi-arid and arid zones is to provide life saving water for crops in the rain season. Microcatchments water harvesting for increasing crop production on dry land has been the subject of considerable research for the last decades. Hackwell $\boldsymbol{e t}$ al. (1991) and Rochester et al. (1994) defined reservoir tillage as a system in which numerous small surface depressions are formed to collect and hold water during rainfall or irrigation to prevent surface run-off. However, currently, reservoir tillage is used predominantly for soil erosion control in environments with higher annual but lower intensity rainfall than semi-arid environments. Typically, depressions are formed in compression by the use of a number of weighted, toothed discs that are towed behind a tractor in recently tilled soils to form isolated, approximately $0.5-\mathrm{L}$ capacity, trapezoidal-shaped impressions in the surface. This method has potential to benefit semi-arid environments. Hansen and Trimmer (1997) reported that reservoirs or basins are created with specialized commercially available tillage machines, which catch and hold water in place until it can infiltrate into the soil. Two basic methods are commonly used to construct reservoirs. One method is pitting-punching holes or depressions 15 to $25 \mathrm{~cm}$ in diameter, 15 to $20 \mathrm{~cm}$ deep, and spaced about $60 \mathrm{~cm}$ on center into the soil. The other method builds up small earthen dams or dikes with a tillage tool that scrapes and carries loose soil down the furrow. The tool trips at preset intervals, creating small dams in the furrows to retain rainwater. Small basins created by these dikes hold the precipitation until it can infiltrate the soil. Ventura et al. (2003) reported a new reservoir tillage system for crop production in semi-arid areas. The system included horizontal soil subsoiler, a modified raw planter and a roller formed with plastic wheels to improve soil tilt and create mini-reservoirs on the soil surface for rain water harvesting. They found that the new reservoir tillage delayed runoff by about 20 minutes over control treatment when a rainfall of $40 \mathrm{~mm} / \mathrm{hr}$ was simulated. Patrick et al. (2007) reported that reservoir tillage is an effective method of harvesting water and thus reducing erosion in semi-arid areas on light textured soils, such as sandy loam soil. Use of marginal areas in semiarid environments for agricultural production commonly includes light textured soils on slopes that are prone to erosion. Also they showed that 
depressions were able to harvest up to $95 \%$ of surface run-off for slopes of up to 10 for the given geometry of the depressions used, this level of water harvesting can be achieved if depressions are orientated with the longitudinal axis across the slope and arranged in a staggered configuration. These results suggest that, for optimized water harvesting, the quell should be operated across slope as is common with other tillage practices on moderate slopes. Therefore, there is a need to design integrated technologies to increase agricultural water use efficiency through rainwater harvesting while conserving the soil in rainfed areas. So, the objectives of this study are to:

- Develop and manufacture a combination unit suitable for water harvesting, planting, and soil conservation under rainfed agricultural conditions.

- Optimize some different operating parameters affecting the performance of the combination unit.

- Evaluate the combination unit from the economic point of view.

\section{MATERIALS AND METHODS}

Field experiments were carried out through two agricultural seasons of 2009/2010 and 2010/2011 at Wadi Madwar, El- Qasr area south west of Marsa Matruh city, in the North-Western Coast. The mechanical analysis of the experimental soil is classified as a sandy loam soil. Soil mechanical analysis and some soil characteristics of the experimental soil are shown in Table (1).

\section{MATERIALS}

1.1. The used crop: Barley (Hordeum vulgar L.) Giza 123 variety was used. The used crop is cultivated in 1 December and harvested in 25 May.

1.2. The irrigation water: Rainfall is the source of irrigation water in the experimental area. In Egypt, rain is considered the main source for agricultural activity particularly in north-west coastal zone. Rain water harvesting in Egypt may secure millions of $\mathrm{m} 3$ of water/year. The main climatic data in the experimental area are shown in Tale (2). The accumulation of rainfall water quantities from December to April are considered the amount of applied water to barley crop. 
Table (1): Some soil characteristics of the experimental soil

\begin{tabular}{|c|c|c|c|c|c|c|c|c|c||}
\hline $\begin{array}{c}\text { Soil } \\
\text { depth, } \\
\mathrm{cm}\end{array}$ & PH & $\begin{array}{c}\text { E.C, } \\
\text { ds.m }\end{array}$ & $\begin{array}{c}\text { Bulk } \\
\text { density, } \\
\mathrm{g} / \mathrm{cm}^{3}\end{array}$ & $\begin{array}{c}\mathrm{Ca} \\
\mathrm{Co}_{3}, \\
\%\end{array}$ & $\begin{array}{c}\text { Particle size distribution, \% } \\
\text { Soil } \\
\text { sand }\end{array}$ & $\begin{array}{c}\text { Fine } \\
\text { sand }\end{array}$ & Silt & Clay & texture \\
\hline $0-20$ & 7.8 & 11.9 & 1.6 & 11.9 & 32.5 & 35.8 & 13.6 & 18.1 & Sandy loam \\
\hline $20-40$ & 7.8 & 15.4 & 1.62 & 15.9 & 24.7 & 43.7 & 12.4 & 19.2 & Sandy loam \\
\hline
\end{tabular}

Table (2): Main climatic data in Matruh, North west, Egypt.

\begin{tabular}{||c|c|c|c|c|c|c|c|c|c|c|c|c||}
\hline \hline \multirow{2}{*}{ Parameter } & \multicolumn{10}{|c||}{ Year months } \\
\cline { 2 - 14 } & Jan & Feb & Mar & Apr & May & June & July & Aug & Sep & Oct & Nov & Des \\
\hline Rainfall, mm/d & 1.29 & 0.71 & 0.40 & 3.80 & 0.13 & 0.04 & 0.00 & 0.03 & 1.50 & 0.05 & 0.79 & 1.20 \\
\hline Max. temp., ${ }^{0} \mathrm{C}$ & 18.0 & 18.8 & 20.2 & 22.8 & 25.9 & 27.1 & 29.1 & 29.8 & 28.6 & 27.0 & 23.3 & 19.8 \\
\hline Min. temp., ${ }^{0} \mathrm{C}$ & 8.0 & 8.1 & 9.6 & 11.7 & 14.5 & 18.1 & 20.1 & 18.1 & 19.6 & 16.7 & 13.2 & 10.0 \\
\hline Air humidity, $\%$ & 61.9 & 58.3 & 57.1 & 57.6 & 57.4 & 59.7 & 64.5 & 63.4 & 62.9 & 51.4 & 64.6 & 60.4 \\
\hline $\mathrm{E} \mathrm{T}_{0}, \mathrm{~mm} / \mathrm{d}$ & 3.0 & 2.87 & 3.87 & 4.87 & 5.33 & 5.27 & 5.27 & 5.83 & 5.0 & 4.33 & 3.33 & 3.0 \\
\hline \hline
\end{tabular}

1.3. The power source: four strokes - Diesel engine tractor of $87 \mathrm{hp}$ $(65.3 \mathrm{~kW})$ was used as a power source

1.4. The local manufactured combination unit: A local manufactured combination unit, suitable for water harvesting, planting, and soil conservation under rainfed agricultural conditions was manufactured from low cost, local material to overcome the problems of high power and high cost requirements under the use of the imported machines. The developed machine is shown in Figs (1 and 2).The combination unit was manufactured and developed in a local engineering workshop, Sharkia Governorate. It consists of the following main parts:

-Frame and wheels: The frame is made of rectangular iron sheet steel. The frame is of $220 \mathrm{~cm}$ length, $210 \mathrm{~cm}$ width and $140 \mathrm{~cm}$ height. It includes elements to fix the chisel plow, the seed drill, the spiked roller and the transmission system. It was carried by two ground wheels of $60 \mathrm{~cm}$ diameter. 

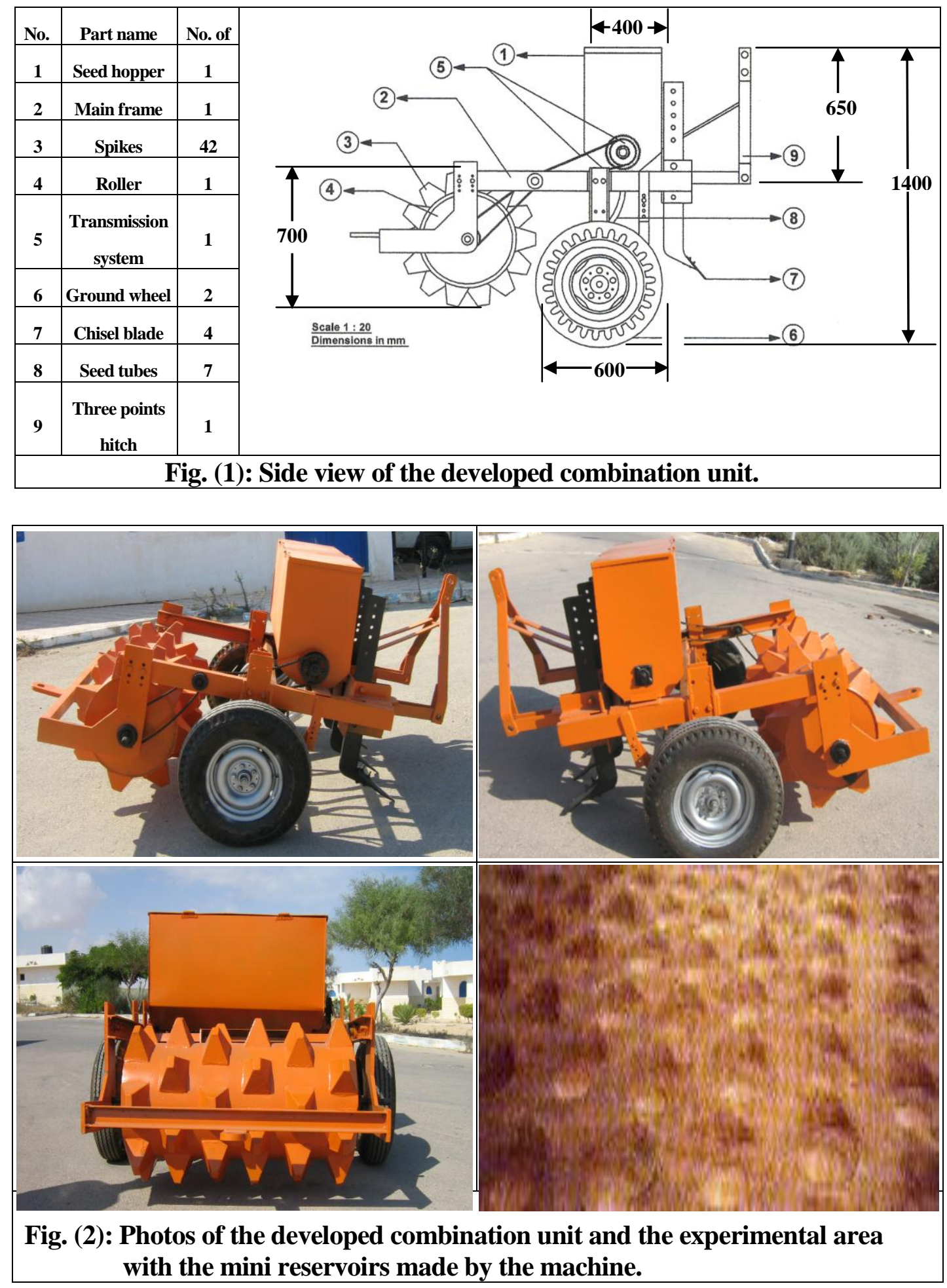
- Four shares chisel plow: Four shares chisel plow were attached to the machine frame. The distance between each two shares is $50 \mathrm{~cm}$. The shares are used to plow the soil to conserve moisture in the effective root zone.

- Seed drill: Seed drill which is attached to the machine frame contains seed hopper, feeding unit, seed tubes and drill coulters. The seed drill is used to carry out mechanical planting in uniform rows ( 7 rows, $25 \mathrm{~cm}$ between each) for planting seed at a controlled depth and in specified amounts.

- Heavy spiked roller: Heavy spiked roller of $150 \mathrm{~cm}$ length and $50 \mathrm{~cm}$ diameter is attached to the machine frame through its shaft. Spikes with a length of $10 \mathrm{~cm}$ are distributed on the roller in rows. The distance between spikes in the same row is $35.5 \mathrm{~cm}$. The spiked roller creates mini-reservoirs (holes) on the soil surface for rainwater harvesting and reduces soil erosion and runoff.

- The transmission system: Motion is transmitted from the machine ground wheel to the seed drill feeding device shaft by means of pulleys and belts with different reduction speed ratios.

\section{2- METHODS}

Experiments were carried out in an area of 2.0 feddans to optimize values of the main operating parameters affecting the performance of the manufactured unit during planting barley.

2.1. Experimental conditions: The performance of the combination unit was experimentally measured under the following parameters:

- Four different forward speeds $(2.5,3.5,4.5$ and $5.5 \mathrm{~km} / \mathrm{h}$

- Four different plowing depths (10, 15 and $20 \mathrm{~cm})$.

2.2. Measurements and determinations: Performance Evaluation of the combination unit was based on the following indicators:

\subsubsection{Soil measurements}

- Soil bulk density: Bulk density was calculated using the following formula (Black et al., 1965):

$$
\rho_{b}=m / v
$$

Where: $\rho_{\mathrm{b}}$ - Soil bulk density, $\mathrm{g} / \mathrm{cm}^{3}$, $\mathrm{m}$ - Soil sample mass, $\mathrm{g}$ and $\mathrm{v}$ - Soil sample volume, $\mathrm{cm}^{3}$. 
- Infiltration rate: Infiltration rate was determined using double ring at three different sites along furrow for each treatment according to (Cuenca 1989).

\subsubsection{Plant measurements}

- Crop yield: Randomized samples of the harvested crop were taken from all treatments to measure the following:

- Grain yield, kg/fed,

- Straw yield, $\mathrm{kg} / \mathrm{fed}$,

- Total yield (Grain Yield + Straw yield), kg/fed.

\subsubsection{Water measurements}

- Runoff: Runoff volume was measured using Girlish trough $(0.5 \mathrm{~m}$ long and $0.2 \mathrm{~m}$ wide), FAO 1993, at the end of slope.

-Water use efficiency (WUE): Water use efficiency was determined as follows:

$$
\operatorname{WUE}\left(\mathrm{kg} / \mathrm{m}^{3}\right)=\frac{\text { Average yield }(\mathrm{kg} / \mathrm{fed})}{\text { Amount ofapplied water }\left(\mathrm{m}^{3} / \mathrm{fed}\right)}
$$

\subsubsection{Combination unit performance Measurements}

- Actual field capacity (F.C act. $_{\text {. }}$ : The actual field capacity was calculated by using the following equation:

$$
F . C_{a c t}=\frac{60}{T u+T l}, \quad(\mathrm{fed} / \mathrm{h})
$$

Where: $\mathrm{T}_{\mathrm{u}}=$ Utilization time per feddan in minutes.

$\mathrm{T}_{1}=$ Summation of lost time per feddan in minutes.

- Field efficiency $\left(\eta_{f}\right)$ : Field efficiency was calculated using the following equation:

$$
\eta_{f}=\frac{F \cdot C_{a c t}}{F \cdot C_{t h}} \times 100(\%)
$$

Where: F. $\mathbf{C}_{\text {th. }}$ - Theoretical field capacity is calculated by multiplying machine forward speed by the effective working width of the machine.

- Fuel consumption: Fuel consumption was recorded by accurately measuring the decrease in fuel level in the fuel tank immediately after executing each operation. 
- Required power: The required power was calculated by using the following formula (Hunt, 1983):

$$
E P=\left[F . C(1 / 3600) P E \times L . C . V \times 427 \times \eta_{t h b} \times \eta_{m} \times 1 / 75 \times 1 / 1.36\right], k W
$$

Where: $f . c=$ Fuel consumption, $(l / \mathrm{h})$.

$\rho E=$ Density of fuel, $(\mathrm{kg} / \mathrm{l})$, (for Gas oil $=0.85)$.

L.C.V = Calorific value of fuel, (11.000 k.cal $/ \mathrm{kg})$.

$\eta_{t h b}=$ Thermal efficiency of the engine, (35\% for Diesel engine).

427 = Thermo-mechanical equivalent, $(\mathrm{kg} \cdot \mathrm{m} / \mathrm{k} \cdot \mathrm{Cal})$.

$\eta_{m}=$ Mechanical efficiency of the engine, (80\% for Diesel engines).

- Energy requirements: Energy requirements can be calculated as follows:

Energy requirements $=\frac{\text { Engine power },(\mathrm{kW})}{\text { Actual field capacity },(\mathrm{fed} / \mathrm{h})}, \mathrm{kW} . \mathrm{h} / \mathrm{fed}$

- Operational cost: The machine cost (Hourly cost) was determined by using the following equation (Awady et al., 1978):

$$
C=\frac{P}{h}\left(\frac{1}{a}+\frac{i}{2}+t+r\right)+(0.9 W \cdot S . F)+\frac{m}{144}
$$

Where:

$C=$ Hourly cost, L.E $/ \mathrm{h} . \quad P=$ Price of machine, L.E.

$h=$ Yearly working hours, h/year. $\quad A=$ Life expectancy of the machine, $\mathrm{y}$.

$i=$ Interest rate/year.

$F=$ Fuel price, L.E $/$.

$t=$ Taxes, over heads ratio.

$R=$ Repairs and maintenance ratio.

$m=$ Monthly average wage, L.E $\quad 0.9=$ Factor accounting for lubrications. $W=$ Engine power, hp. $\quad S=$ Specific fuel consumption, $l / h p . h$. $144=$ Reasonable estimation of monthly working hours.

The operational cost can be determined using the following formula:

$$
\text { Operational cost }=\frac{\text { Machine } \operatorname{cost}(L . E / h)}{\text { Actual field capacity }(f e d / h)},(\text { L.E/ fed })
$$

\section{RESULTS AND DISCUSSION}

The discussion will cover the obtained results under the following heads:

\section{Effect of some operating parameters on soil characteristics}

Results in Fig. (3) show that there are differences in soil bulk density and infiltration rate before and after using the combination unit. Bulk density 


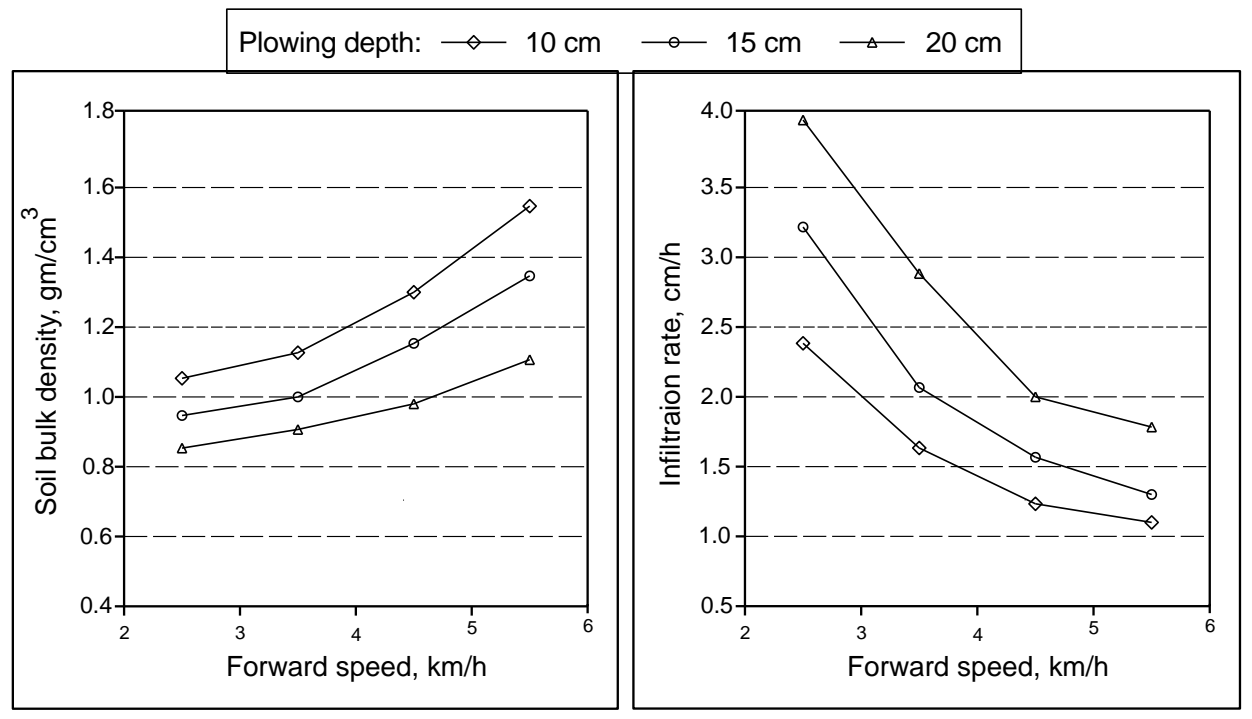

Fig. (3): Effect of machine forward speed on soil bulk density and infiltration rate under different plowing depths.

generally decreased due to tillage while the vice versa is noticed with the infiltration rate. The maximum reduction of $43 \%$ in bulk density, while the maximum increase in infiltration rate of $29 \%$ were observed under forward speed of $2.5 \mathrm{~km} / \mathrm{h}$ and plowing depth of $20 \mathrm{~cm}$. This can be explained by the fact that bulk density decreased while infiltration rate increased due to tillage because of the breakdown of soil structure, increase pore spaces and therefore reduce bulk density. The same results also show that increasing machine forward speed increased bulk density while decreased infiltration rate. Increasing machine forward speed from 2.5 to $5.5 \mathrm{~km} / \mathrm{h}$ increased bulk density from 0.95 to $1.35 \mathrm{~g} / \mathrm{cm}^{3}$, while decreased the infiltration rate from 3.2 to $1.3 \mathrm{~cm} / \mathrm{h}$ at a plowing depth of $15 \mathrm{~cm}$. This increase in bulk density and the decrease in infiltration rate by increasing forward speed are because of producing fewer breakdowns of soil aggregates. The obtained data also show that increasing plowing depth decreased bulk density while increased the infiltration rate. Increasing plowing depth from $10 \mathrm{~cm}$ to $20 \mathrm{~cm}$ decreased bulk density from 1.12 to $0.9 \mathrm{~g} / \mathrm{cm}^{3}$, while increased the infiltration rate from 1.6 to $2.8 \mathrm{~cm} / \mathrm{h}$ at a forward speed of $3.5 \mathrm{~km} / \mathrm{h}$. This decrease in both bulk density and the increase in the infiltration rate by increasing plowing depth are attributed to the increase in soil crumbling and pore spaces. 


\section{Effect of some operating parameters on crop characteristics}

Tillage as well as machine operating parameters has a great effect on the crop characteristics such as: grain yield and total crop yield. It was observed in Fig. (4) that the maximum grain yield of $920 \mathrm{~kg} / \mathrm{fed}$ was remarked under forward speed of $2.5 \mathrm{~km} / \mathrm{h}$ and plowing depth of $20 \mathrm{~cm}$. It decreased to 500 $\mathrm{kg} / \mathrm{fed}$ under forward speed of $5.5 \mathrm{~km} / \mathrm{h}$ and plowing depth of $10 \mathrm{~cm}$. Also data show that the maximum total crop yield of $3900 \mathrm{~kg} / \mathrm{fed}$ was noticed under forward speed of $2.5 \mathrm{~km} / \mathrm{h}$ and plowing depth of $20 \mathrm{~cm}$ while decreased to $1800 \mathrm{~kg} / \mathrm{fed}$ under forward speed of $5.5 \mathrm{~km} / \mathrm{h}$ and plowing depth of $10 \mathrm{~cm}$. The decrease in both grain yield and total crop yield by increasing machine forward speed is due to the fact that the increase in forward speed affected structural stability and state of soil compaction of disturbed soil added to the increase of machine vibration resulting in an increase in seed scattering which affects negatively on crop yield. While the increase in grain yield and total crop yield by increasing plowing depth is due to the increase in soil pulverization.
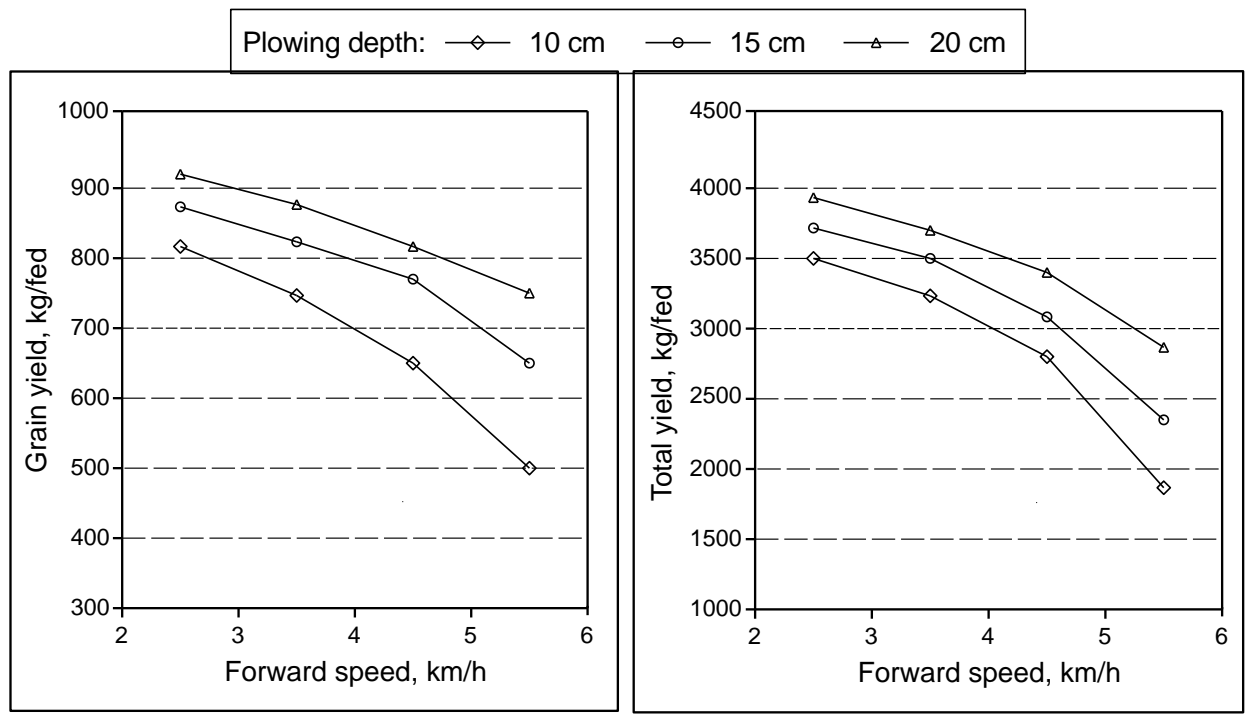

Fig. (4): Effect of machine forward speed on crop yield under different plowing depths.

Added to that, the stored water in the mini reservoirs, which are made by the developed machine, helps in increasing crop yield.

\section{Effect of some operating parameters on water characteristics}


Water characteristics are more sensitive to tillage and machine operating parameters. The developed combination unit decreases runoff and improves water use efficiency. The values of runoff and water use efficiency are shown in Fig. (5). The minimum value of runoff and the maximum value of water use efficiency were $2.36 \mathrm{~mm}$ and $2.25 \mathrm{~kg} / \mathrm{m}^{3}$ respectively under forward speed of $2.5 \mathrm{~km} / \mathrm{h}$ and plowing depth of $20 \mathrm{~cm}$. While the maximum and minimum values were $4.8 \mathrm{~mm}$ and $1 \mathrm{~kg} / \mathrm{m}^{3}$ under forward speed of $5.5 \mathrm{~km} / \mathrm{h}$ and plowing depth of $10 \mathrm{~cm}$ under the same previous conditions. The increase in runoff and the decrease in water use efficiency by increasing machine forward speed are attributed to the fact that the minireservoirs created by the developed machine at high speeds can not collect or store rainfall due to its bad form resulting from machine vibration. While the decrease in runoff and the increase in water use efficiency by increasing plowing depth is due to the fact that rainfall was collected in the minireservoirs made by the developed machine, allowing more time for infiltration which reduced runoff and increased water use efficiency.

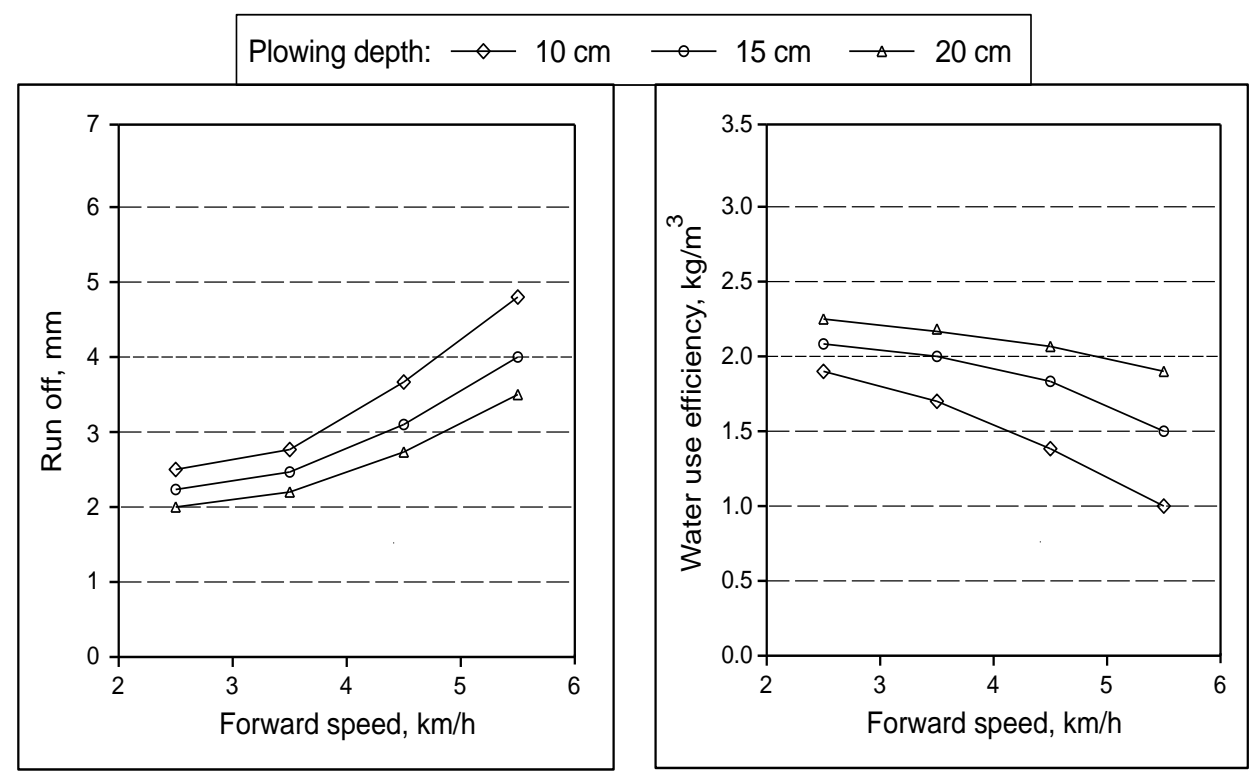

Fig. (5): Effect of machine forward speed on runoff and water use efficiency under different plowing depths. 


\section{Effect of some operating parameters on field capacity and field efficiency}

The effect of both forward speed and plowing depth on field capacity and field efficiency is shown in Fig. (6). Obtained results show a remarkable drop in the field efficiency with a consequent sharp rise in the field capacity as the forward speed increased, while the vice versa is noticed with the plowing depth. Increasing forward speed from 2.5 to $5.5 \mathrm{~km} / \mathrm{h}$ increased field capacity from 1.05 to 1.78 , from 1.0 to 1.5 and from 0.95 to $1.25 \mathrm{fed} / \mathrm{h}$, at plowing depths of 10,15 , and $20 \mathrm{~cm}$ respectively. The vice versa was noticed with the field efficiency, where the field efficiency decreased from 88 to 68 , from 84 to 57 , and from 80 to $50 \%$ under the same previous conditions. The major reason for the reduction in field efficiency as the forward speed increased is due to the less theoretical time consumed in comparison with the other items of time losses.

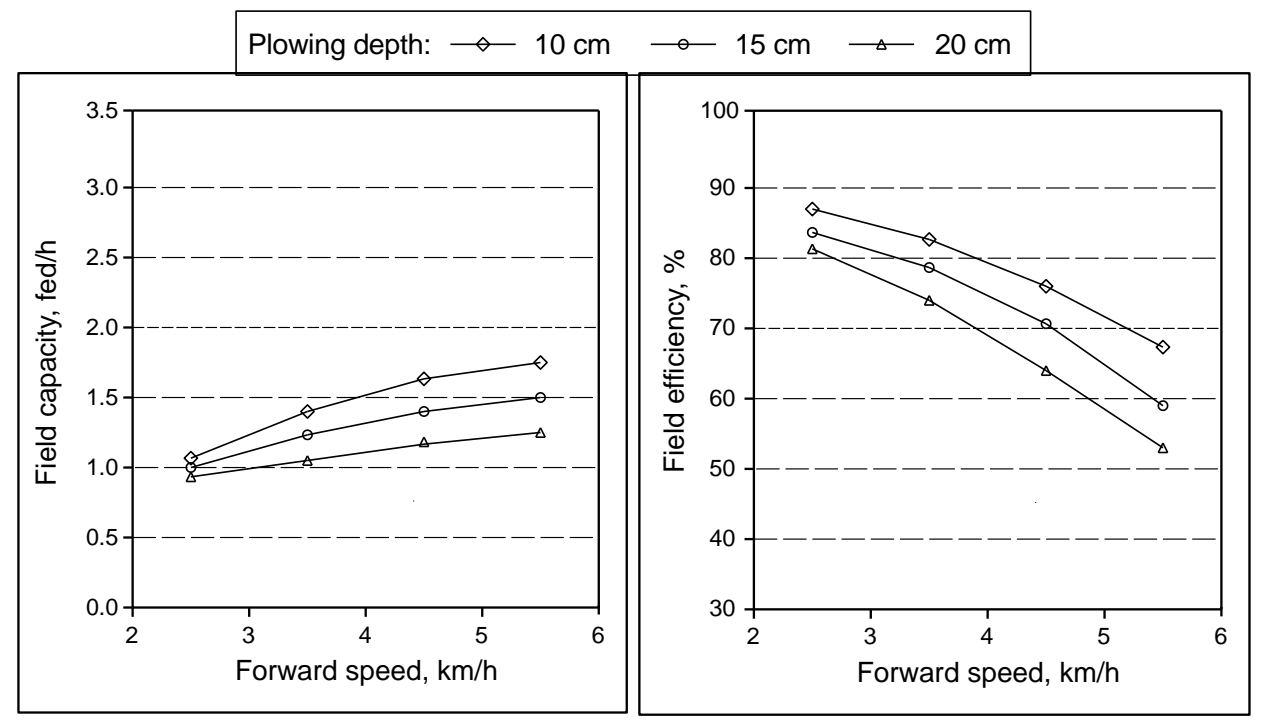

Fig. (6): Effect of machine forward speed on field capacity and field efficiency under different plowing depths.

\section{Effect of some operating parameters on fuel, power and energy requirements}

Power and energy requirements are highly affected by both forward speed and plowing depth. Fig. (7) shows a remarkable drop in energy requirements 
as the forward speed increased up to $4.5 \mathrm{~km} / \mathrm{h}$. Any further increase in forward speed more than $4.5 \mathrm{~km} / \mathrm{h}$ up to $5.5 \mathrm{~km} / \mathrm{h}$ energy will increase, while required power increased all time by increasing forward speed. Increasing forward speed from 2.5 to $5.5 \mathrm{~km} / \mathrm{h}$, increased the required power from 18 to 26 from 19.5 to 29 and from 21 to $33 \mathrm{~kW}$ at plowing depths of 10,15 and $20 \mathrm{~cm}$ respectively. While increasing forward speed from 2.5 to $4.5 \mathrm{~km} / \mathrm{h}$, decreased energy requirements from 17 to 13 , from 20 to 17 and from 22 to $19.5 \mathrm{~kW}-\mathrm{h} /$ fed. Any further increase in forward speed from 4.5 up to $5.5 \mathrm{~km} / \mathrm{h}$, energy requirements will increase from 13 to 15 , from 17 to 19 and from 19.5 to $25 \mathrm{~kW}$-h/fed under the same previous conditions. The decrease in energy requirements by increasing forward speed up to $4.5 \mathrm{~km} / \mathrm{h}$ is attributed to the increase in field capacity, while the increase in energy requirements by increasing forward speed from $4.5 \mathrm{up}$ to $5.5 \mathrm{~km} / \mathrm{h}$ is due to that the rate of increase in power is more than the rate of increase in field capacity.

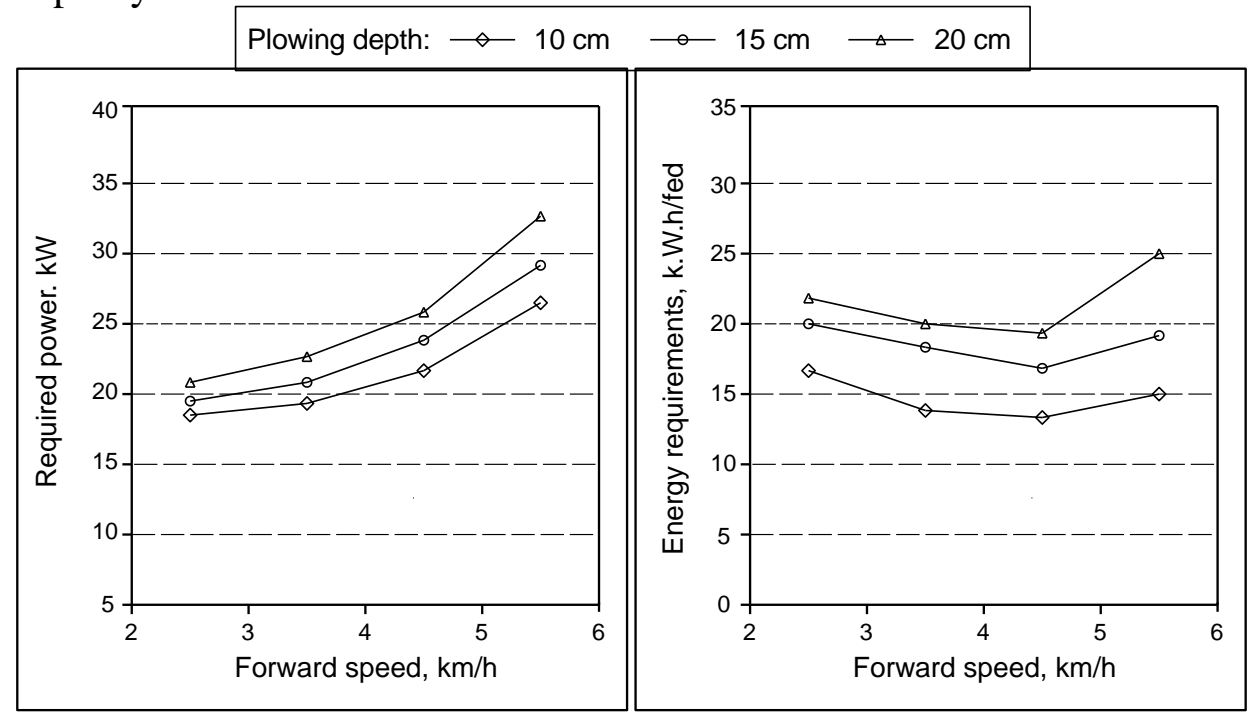

Fig. (7): Effect of machine forward speed on required power and energy requirements under different plowing depths.

\section{Effect of some operating parameters on operational cost}

From the economical point of view, results show that the hourly cost increased as the forward speed increased, while the vice versa was noticed with the operational cost which decreased in the speed range from 2.5 up to 
$4.5 \mathrm{~km} / \mathrm{h}$, while any further increase in speed more than 4.5 up to $5.5 \mathrm{~km} / \mathrm{h}$ operational cost will increase Results in Fig. (8) show that increasing forward speed from 2.5 to $5.5 \mathrm{~km} / \mathrm{h}$, increased hourly cost from 55 to 62 , from 57 to 65 and from 60 to 70 L.E./h, at plowing depths of 10, 15 and 20 $\mathrm{cm}$ respectively. Referring to the operational cost, results also show that increasing forward speed from 2.5 to $4.5 \mathrm{~km} / \mathrm{h}$ decreased operational cost from 52 to 37, from 57 to 45 and from 63 to 53 L.E. /h. Any further increase in speed from 4.5 up to $5.5 \mathrm{~km} / \mathrm{h}$, operational cost will increase from 37 to 38, from 45 to 46 and from 53 to 55 L.E. /h. The decrease in operational cost by increasing forward speed is attributed to the increase of machine field capacity, while the increase in operational cost by increasing forward speed from 4.5 up to $5.5 \mathrm{~km} / \mathrm{h}$ is due to that the rate of increase in hourly cost is more than the rate of increase in field capacity. The obtained data also show that increasing plowing depth increased both hourly and operational costs. Increasing plowing depth from $10 \mathrm{~cm}$ to $20 \mathrm{~cm}$ increased the hourly cost from 56 to 61 L.E./h, also increased operational cost from 39 to 54 L.E./fed at a forward speed of $3.5 \mathrm{~km} / \mathrm{h}$. This increase in both hourly and operational costs by increasing plowing depth is attributed to the increase in soil resistance resulting in high fuel consumption and low field capacity under high depths.

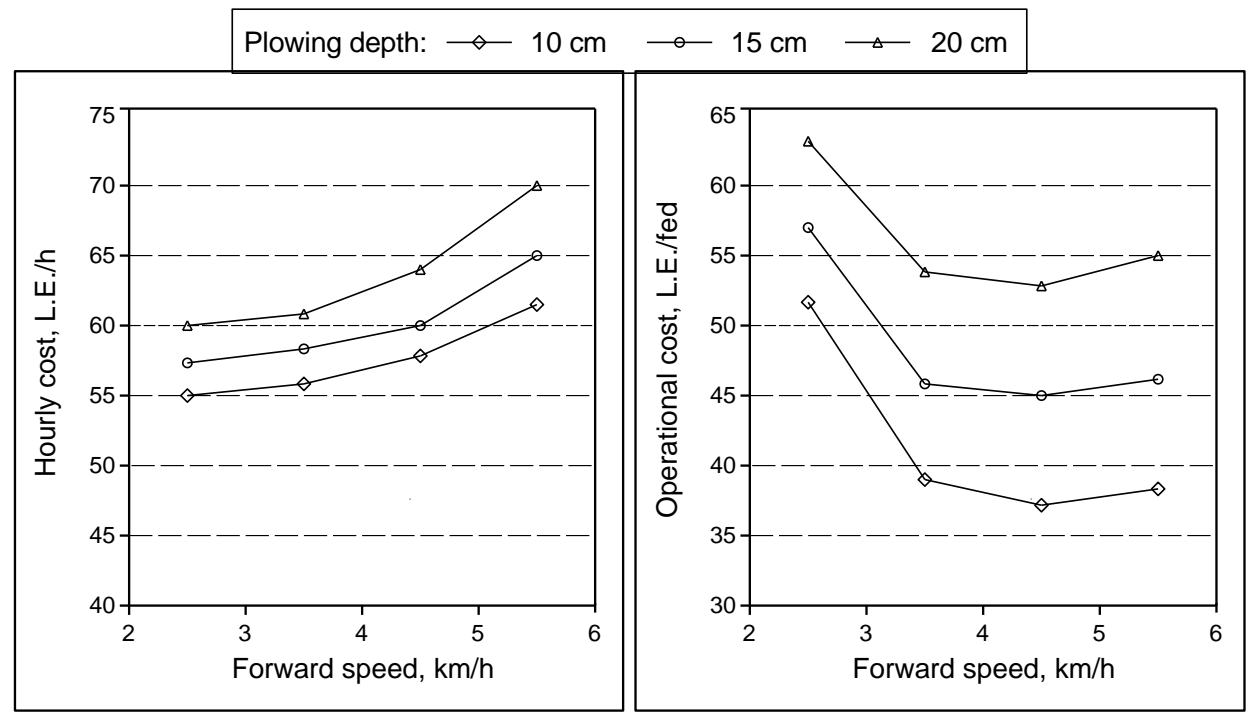

Fig. (8): Effect of machine forward speed on hourly cost and operational cost under different plowing depths. 


\section{CONCLUSION}

The experimental results reveal that energy requirements as well as criterion costs were minimum while crop yield and water use efficiency were maximum under the following conditions:

- Operate the developed machine at a forward speed of between 3.5 to $4.5 \mathrm{~km} / \mathrm{h}$.

- Operate the developed machine at a plowing depth of between 10 to $15 \mathrm{~cm}$.

\section{REFERENCES}

Awady, M. N. (1978): Tractor and farm machinery . Txt bk., Col. Ag., Ain Shams U.: 146-167.

Black, C. A; D. D. Evan; J.L. White; L. E. Ensimenger and L.E. Clark (1965): Methods of soil analysis. Publisher Wisconsin, USA.

Cuenca, R. H. (1989). Irrigation system - An Engineering Approach. Prentic - Hall, Inc., Englewood cliffs, NJ. 552pp.

FAO (1993): Field measurements of soil erosion and runoff. Soils Bull. No (68). Rome, Italy.

Hackwell, S. G; E. W. Rochester, K. H. Yoo, E. C. Burt and G. E. Monroe (1991): Impact of reservoir tillage on water intake and soil erosion. Transactions of the American Society of Agricultural Engineers, 34, 436-442.

Hansen, H. and W. Trimmer (1997): Irrigation Runoff Control Strategies. Oregon State University Extension Service Publication. PNW 287.

Hunt, D. (1983): Farm power and machinery management. 8th Ed. Iowa state Univ., Press Ames, Iows, USA: 364-368.

Patrick, C; C. Kechavarzi, I. T. James, M. O'Dogherty and R. J. Godwin (2007): Developing reservoir tillage technology for semi-arid environments. British Society of Soil Science, Soil Use and Management, 23, 185-191.

Rochester, E. W; D. T. Hill and K. H. Yoo (1994): Impact of reservoir tillage on run-off quality and quantity. Transactions of the American Society of Agricultural Engineers, 37(4), 1183-1186.

Ventura, E; L. D. Norton, K. Ward, M. López-Bautista and A. TapiaNaranjo (2003): A New Reservoir Tillage System for Crop Production in Semiarid Areas. 2003 ASAE Annual Meeting. American Society of Agricultural Engineers. 


\section{الملخص العربيى}

تصنيع وتقييم أداء وحدة مجمعة لتناسب حصاد المياه وصيانة الأراضي

تحت ظروف الزراعات المطرية

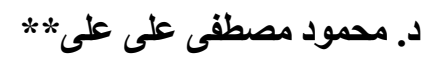

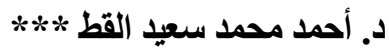

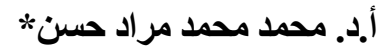

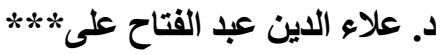

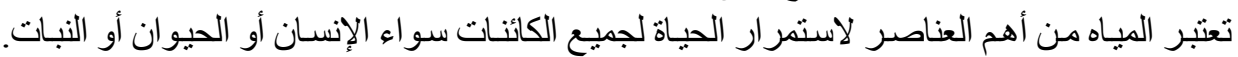

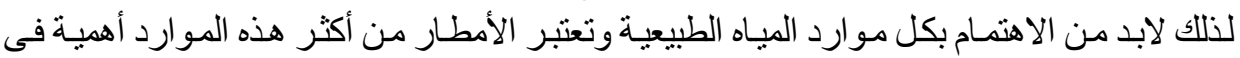

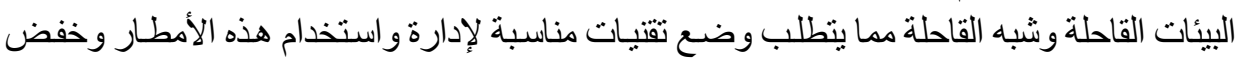

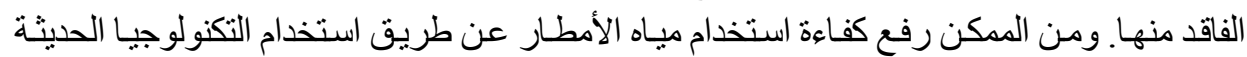

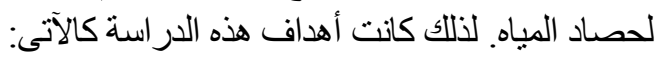

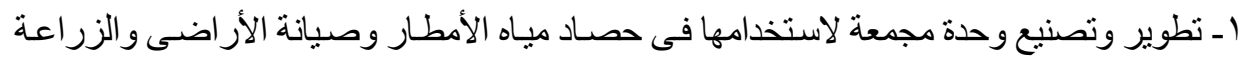
في مناطق الزر اعات المطرية.

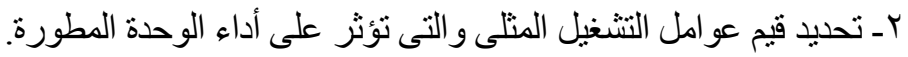
بـ ـ تقييم الوحدة المطورة اقتصاديا.

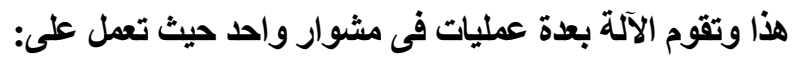

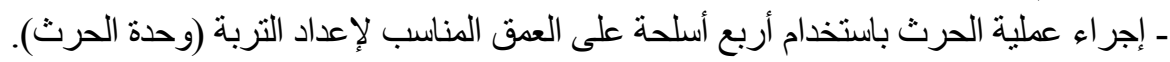

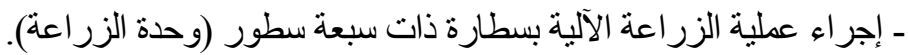

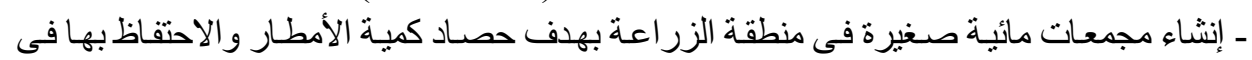
منطقة انتشار الجذور (وحدة حصاد مياه الأمطار).

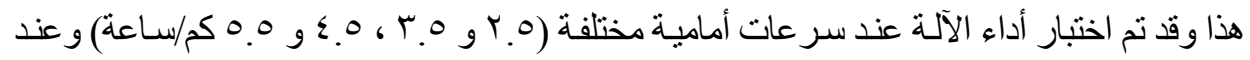

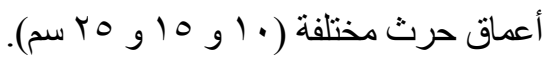

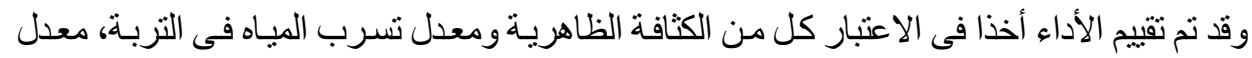

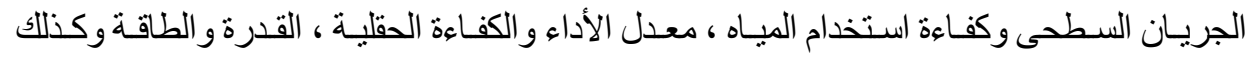

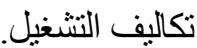
وقث أظهرت النتائج التجريبية أن كل من متطلبات الطاقة والتكاليف الكلية تكون فى أدنى قيمها وأن

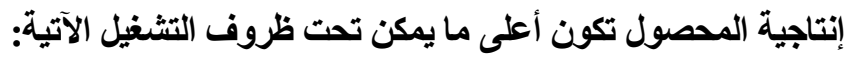

ـ استخدام الوحدة المجمعة فى عملية حصاد المياه وصيانة التربة التئ.

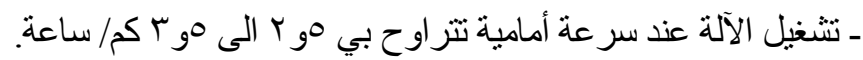

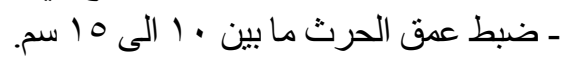

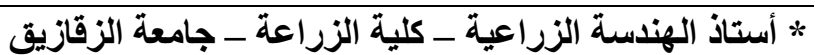

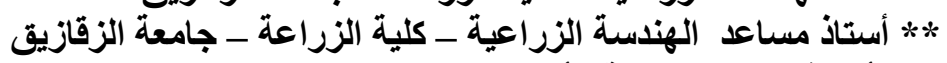

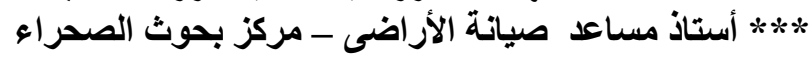

